Јелена Радовић Јовановић

Радио-телевизија Србије
УДК 316.7:004

ДОИ https://doi.org/10.18485/

melissa.2016.15.2.ch12

\title{
ВИРТУЕЛНА СТВАРНОСТ: БРИСАЊЕ ГРАНИЦА КЛАСИЧНОГ КОНЦЕПТА РЕАЛНОСТИ И ИНДИВИДУАЛНИХ РАЗЛИКА
}

\section{Сажетак}

Глобална постмодерна илузија реалности истиче сву лепоту културних различитости али представља и претњу да их учини међусобно сличнијим или да их сасвим избрише. Нове медијске платформе константно опскрбљују процес глобализације свим неопходним елементима.

Глобализација је екстензивни, интерактивни и живи комуникацијски модел и добар део тог процеса се одвија у виртуелним просторима нових медијских платформи. У самом срцу тог комуникацијског глобуса су многобројне везе које убрзано јачају. Та лопта се убрзано увећава тако да ни границе ни величине нису применљиве варијабле кад је реч о овом динамском концепту. То место је инспирација за прављење првих корака ка новој креацији која одбацује пасивност и анагажује свесни критички приступ.

Важни делови ове виртуелне слагалице су персонални сајтови а одмах уз њих су и бројни комерцијални сајтови чији активни чланови трагају за оним корисницима интернета који би могли у будућности постати добри клијенти или потрошачи одређених роба и услуга. Виртуелне друштвене мреже прерасле су у скоро реална места на којима је лако добити друштвену подршку, прихватање и одобравање.

Процес културне размене на новим медијским платформама спушта се до нивоа сваког појединог корисника док ми и не примећујемо убрзавање процеса рађања једног новог глобалног културног ентитета. Већ сада тај глобални медијски систем може представљати и одраз културног империјализма. Извоз медијских садржаја путем нових компјутерских технологија обезбеђује доминацију и превласт медијских садржаја из само једне или тек неколико земаља, и то путем индустрије маркетинга и забаве или извоз неке локалне поп културе која потом представља удар на културне особености осталих људи и земаља. Припадници антиглобалистичког покрета наглашавају ову опасност од неповратног нестајања културних различитости. На другој страни су глобалисти који наглашавају значај окупљања различитости на једном месту и развоја толеранције за све врсте међусобних разлика. Колико јуче је било скоро сасвим немогуће окупити толико људи на једном месту док је сада ту овај нови облик реалности, назване виртуелном, која има огроман утицај на оном месту које још увек сматрамо истинским реалним простором. 
Кључне речи: Илузија реалности, културне различитости, културна глобализација, стварни и виртуелни простор, комуникацијски глобус, динамски концепт, персонални и комерцијални сајтови, глобални културни ентитет, културни империјализам, културолошка особеност

\section{Увод}

Виртуелна комуникација почива на новим културним обрасцима који су настали и развијају се на технолошкој основи и полако али дефинитивно преузимају и унапређују старе облике међуљудске комуникације. Компјутерске мреже и платформе су нови простор за комуникацију који има велики утицај на све појединце који их користе било као ефикасан облик комуникације, као забаву или садржај усмерен ка неком едукативном или пословном циљу. Прошло је време у којем је физичко, материјално окружење доминирало нашим животима и представљало основни критеријум и елемент реалности.

Интернет технологије представљају средство за креирање и размену информација на начин који до недавно није било могуће замислити. То је резултирало пребукираношћу информацијама а реакција јавности би могла бити, супротно очекиваној радозналости, обично игнорисање података, сматра Гери Барнет (Jaeger and Burnett 6).

Негативан ефекат на успешно усвајање података могу имати и и културолошки неразумљиве чињенице које због тога неће бити ни запамћене. Проблем прекомерног броја података, о којем пише Барнет, није исто што и проблем квалитета информација. Интернет сајтови обилују произвољним и нетачним али и тачним и научно доказаним информацијама а почетнику је тешко да разликује праве информације од оних које потичу из површних, лаичких, неозбиљних и неупућених извора. У овом контексту, више није питање само шта је реално а шта виртуелно, већ да ли виртуелно значи уједно и много мање поуздано, непрецизно и као такво некорисно. Поставља се и питање механизама и критеријума за процену поузданости виртуелних извора информација. Укратко, како разликовати шта је добро, тачно и корисно у виртуелном извору и како то знање, савете или бројне информације усвојити без губитка критичке дистанце. 
Стивен Џоунс сматра да је наша очекивања у вези са новим комуникационим технологијама могуће сврстати у три основне области: саобраћај или кретање, комуникације и сигурно похрањивање података (Jones 3).

Када прикупљамо искуство, ми тражимо и неко место на које ћемо га сместити. Изгледа да је немогуће непрекидно додавати предмете, симболе или процесе нашим животима а да се ничег претходног не одрекнемо. Стога, да бисмо све сачували, морамо пронаћи било реални било виртуелни простор за то- објаснио је Џоунс важност потребе за трајним чувањем података (Jones 4).

Данас када некога запитамо: - Где желите да идете?-, ми не мислимо буквално већ најчешће виртуелно. Није се променило само схватање појма кретање већ и семантички карактер уобичајених реченица. Ми путујемо виртуелно, ми комуницирамо виртуелно, ми чувамо искуство и знања од заборава у виртуелном магацину. Како онда уопште можемо да кажемо да виртуелни свет не представља реалност, да није реалан?

\section{Виртуелна глобализација и глобализација културе}

Културна глобализација у великој мери почива на виртуелној глобализацији. Почетак лежи у речима односно језику довољно разумљивом свим учесницима виртуелне комуникације. Када је реч о модерној, виртуелној култури, једна од важних полемика се води на тему глобализације, између њених присталица и њених противника. И једни и други мисле на глобализацију као комплексан процес који захвата и тржиште роба, и медије, и културу. Највећи замајац том општем процесу сигурно дају могућности нових медија. Када говоримо о глобализацији као културном феномену, мислимо првенствено на културне обрасце комуникације настале у виртуелном простору али и на јачање а још много чешће на брисање културних особености или различитости. 


\section{Комуникација}

Глобализација на плану комуникације је интерактиван и жив комуникацијски модел и велики део тог процеса се одвија у виртуелним просторима нових медијских платформи. У самом срцу тог комуникацијског глобуса су многобројне везе које убрзано јачају. Та лопта се убрзано увећава тако да ни границе ни величине нису применљиве варијабле кад је реч о овом динамском концепту. То место је инспирација за прављење првих корака ка новој стварности која одбацује пасивност и анагажује свесни критички приступ.

Глобализација није започела тек у виртуелној ери. Међународна економија је прво поље глобализације и тај процес је започео много пре појаве интернета и нових комуникацијских форми. Холмс сматра да прапочеци датирају вековима уназад.

Економска глобализација постоји већ веома дуго, ношена војним, политичким империјализмом широм света на неравномеран начин још од 16. века (Holmes 2).

Међутим, све до изградње путева и развоја транспортних средстава, није могуће говорити о глобалном и убрзаном процесу повезивања. У том смислу је направљен прави искорак тек почетком 20. века. То доба је било обележено друштвено-политичким променама.

Холмс сматра да је међусобна размена ставова код нација и посебно припадника радничке класе почела на самом почетку 20. века а допринос томе је дала теорија Маркса и Енгелса (Holmes 2)

У то време је настао интернационални телеграфски систем за комуникације које се тичу финансијских трансакција широм света. Данас се много више говори о концентрацији капитала него о глобализацији јер су финансијске трансакције, и поред развијеног светског тржишта, махом сведене на најмоћније економије: Европу, Америку, Кину и Јапан. Осим тога, данас су медији много чешћа тема у причи о глобализацији него што су то директно економска питања.

Постоје три различита основна приступа и дефиниције културе који на различит начин интерпретирају комуникацију. То су антроплошка, културолошка и глобализацијска дефиниција. 
- Антрополошка дефиниција третира културу као размену значења а комуникацију као прослеђивање и размену информација између група људи или појединаца. У овом случају, културне вредности и други њени елементи се међусобно размењују међу члановима групе.

- У културолошкој дефиницији, комуникација је процес у којем појединци и групе преговарају са циљем да се сложе око семантичких питања односно око различитих значења онога што се приписује реалности. На крају дебате, нека гледишта постају стандард а друга се маргинализују или прећутно подразумевају. Дакле, комуникација је по томе, пре свега преговарање, борба за моћ и препознатљивост па тек потом размена значења.

У дефиницији комуникације под светлом глобализације, комуникација је извор, продуктивни процес који води ка промени. Води до изједначења, изградње колективног идентитета а са циљем да се пробуди и искористи на позитиван начин лични, економски или политички потенцијал. Комуникација је искоришћавање свих могућих доступних извора. Културни обрасци су у некој врсти конкуренције јер постоје материјалне и симболичке последице или импликације које се доводе у везу са првим, другим или трећим приступом комуникацији (Sorrells 10).

\section{Илузија реалности и могућности кретања}

Глобална постмодерна илузија реалности истиче сву лепоту културних различитости али представља и претњу да их учини међусобно сличнијим или да их чак сасвим избрише. Нове медијске платформе константно опскрбљују процес глобализације свим неопходним елементима. Нова култура глобализма је директна последица мешања центара културних различитости. Миграције, туризам и телекомуникације су постале најмоћнији агенси глобализације поред медија. Док смо некада сазнавали о удаљеним местима на планети захваљујући новинама, филмовима и ретким путовањима, данас тамо стижемо одмах и лако, померањем културних граница и коришћењем модерне технологије. 
Ипоредтога што је економија увек база економскуглобализацију надилази медијска културна глобализација. Иако је простор без сумње и даље реална категорија, данас када се он досеже путем интернета, вруће питање постаје време и то нарочито у аспектима брзине протока информација, благовремене доступности аудио и видео материјала и брзине комуникације међу удаљеним учесницима исте. Виртуализација је још сложенији, општији појам који искривљује и простор и време. То је врста сабијања али и распарчавања и мешања искустава разних културних заједница.

Ми живимо у доба стално отворених система комуникације који се не могу свести на само један контекст какав би био сајбер простор већ је у питању невиђена могућност и брзина свеопштег кретања и мешања материјалне и нематеријалне стварности. Простор и даље остаје реална и обавезна категорија јер „они који су објавили смрт свакој дистанци остају при томе да су инстант комуникације интернета и интранета довеле до лабављења и колапса просторних и временских веза а то чак до радикалне компресије времена и простора што опет ослобађа друштвене односе и односе капитала од модернистичке спацијалне, просторне логике. Просторна логика се може скоро сасвим одбацити само ако би постојала једнака могућност производње и потрошње којој би сваки појединац имао приступ. Међутим, тај приступ није дистрибуиран равномерно ни унутар држава ни између њих. Географија се не може сасвим елиминисати, она остаје важан организациони принцип и конституент друштвених односа“(Dodge 13-14).

Једини простор на планети који је посећен и насељен свакодневно јесте виртуелни простор. Док се посленици туризма труде да направе атрактивне локације, тематске паркове и сл. не би ли привукли што више посетилаца, виртуелна мрежа је добровољно посећена и дању и ноћу а број посетилаца вртоглаво расте.

Идеја виртуелног простора се најчешће схвата као компјутерски посредовано управљање људским чулима. Сајбер простор је компонован од компјутерски посредованих речи, у којем може да настане првенствено она комуникација која је заснована на тексту. Оно што омогућава медиј је само процесуирање тока типографских информација (Holmes 6). 
Парадокс модерног начина живота лежи у контрасту свакодневне рутине и невиђених могућности нових облика комуникације, едукације, пословања, забаве итд.

Док већина људи наставља да живи у својој малој локалној средини и стварности, та иста стварност трпи изазове и бива инкорпорирана у велику глобалну мрежу међуљудских односа. Та нова слика друштва нас позива да преиспитамо вредности, морал, компетиције и вештине неопходне за ову глобалну трансформацију друштва на платформи убрзаног развоја компјутерских и комуникацијских технологија.

Да би дошло до јасне квалитативне измене концепта реалности у смислу брисања границе физичког и виртуелног света, потребно је да димензије простор и време доживе суштинске промене, чак и девијације а паралелно с тим процесом, да дође до промене идентитета и синтезе, прихватања али и брисања културних и других различитости.

\section{Национални, културни и мултикултурни идентитет}

Глобализација мења начин на који ми доживљавамо национални идентитет. Све политичке, културне и остале границе су избледеле. Сада се језици, територије и појединци разумеју и слажу боље него икад. Гранични конфликти каквих има на терену између држава, не постоје у виртуелном свету.

Док је културни идентитет јасно постављен, лоциран осећај себе или сопственог Ја који је обликован културолошким искуством и одређеном друштвеном позицијом и географском локацијом (Sorrells 11), мултикултурни идентитет се рађа најпре тамо где се највише мешају различитости, данас је то на компјутерским комуникацијским платформама, а потом и на географским локацијама које представљају место сусрета различитости, услед убрзаних миграција, економских, политичких, породичних и осталих.

3бог веће покретљивости становништва и бољег познавања чињеница, многе државе су постале мултикултурне, нарочито оне 
развијеније које привлаче мигранте. У тим земљама се намеће нова потреба помирења разлика и управљања различитостима на праведан начин а није лако разумети и помирити разлике. То се лакше одвија на интернету и зато је могуће претпоставити да ће данашњи млади у будућности лакше решавати у пракси ова питања управо захваљујући великом искуству на пољу интеркултурних и виртуелних комуникација. Они ће употребити деценијама стицана знања, искуства и вештине да би допринели помирењу разлика али и одржању посебности и вредних културолошких различитости.

Будуће вештине, неопходне за развој праведног мултикултурног друштва, биће:

- мултидисциплинарна знања,

- способност анализе проблема из различитих углова,

- мисаона флексибилност и могућност предвиђања,

- познавање различитих култура уз одбацивање предрасуда и

- способност сарадње са групама потпуно различитих појединаца.

Све то је управо онај комплекс знања и вештина који се може стећи у виртуелном окружењу.

Најмање две личне особине односно вештине са списка пожељних и неопходних за изазове будућности су карактеристичне за креативне особе. У Норвешкој школи бизниса је спроведена студија са циљем идентификовања основних особина креативних личности (Martinsen 185-202). Флексибилност која се испољава као способност сагледавања ствари из различитих углова и осмишљавања више могућих решења неког проблема је једна од тих особина. У корелацији је са проницљивошћу и често удружена са склоношћу ка асоцијативношћу и добрим сналажењем и у свету фикције и у реалном свету. Све то указује на креативност као основни услов адаптације и сналажења у новој реалности која је плод синтезе физичке и виртуелне.

\section{Сајтови, мреже и платформе као виртуелни станови}

Важни делови виртуелне слагалице су персонални сајтови који обезбеђују додатни простор за изражавање индивидуалног и култур- 
ног идентитета. Одмах уз њих су и бројни комерцијални сајтови чији активни чланови трагају за оним корисницима интернета који би могли у будућности постати добри клијенти или потрошачи одређених роба и услуга. Виртуелне друштвене мреже прерасле су у скоро реална места на којима је лако могуће добити друштвену подршку, прихватање и одобравање.

Виртуелне групе истомишљеника су као веће породице у којима се размењују блискост, приватност и речи подршке. Поред тога, већина нових платформи и друштвених мрежа захтева одређене податке о кориснику, слике, адресе а понекад и банковне бројеве. Сајбер криминал је бржи, лакши, исплатљивији и доступнији од традиционалних облика криминалног лова. Технологија је постала наша нова култура али и некултура. Због брзине технолошког развоја, поставља се питање у ком смеру се развија виртуелна култура и које безбедносне мере је потребно одмах применити ради превенције злоупотреба. Такође је важно посматрати са дистанце овај феномен модерног доба да би се лакше уочиле глобалне друштвене тенденције настале као последица овог културног скока.

У почетку су друштвене мреже привукле велики број младих корисника који су ту налазили психолошку подршку, били раме за плакање или нечије друштво доступно и отворено за контакт у сваком тренутку. Временом, како се повећавао број корисника али се мењала и њихова старосна структура, мреже су постале и мета изопачених или криминалних идеја појединих корисника. Највећу опасност представља злоупотреба малолетника и то најчешће у оним моментима када се чини искорак у објективну стварност.

\section{Лични идентитет}

Идентитет је најрањивије питање на виртуелним сајтовима и мрежама. Могућности лажног представљања и прикривања правих мотива комуникације су далеко веће него приликом сусрета у стварном свету. Човек који има потребу да пласира идеалну слику о себи као особи каква би заправо желео да буде, сада има невиђене 
могућности да то и учини. Зато овај донекле природни психолошки порив да се избегне конфронтација са сопственим манама, добија шансу да се без препрека реализује у том донекле нереалном окружењу, у неким случајевима до нивоа девијације.

Посебно питање представља утицај овако грађене слике о себи код врло младих који, потом, када кроче у неумољиву стварност која задаје праве ударце, доживљавају фрустрацију, одбацивање, исмевање околине и све их то баца назад у таму собе у којој их чека виртуелно друштво које олако опрашта и површно схвата приче о туђим стварним животима.

И поред визуелних могућности интернета, сусрет у објективном свету много више обилује визуелним детаљима. Ту је изглед саговорника, боја очију, изрази лица, одећа, окружење итд. Све то помало скреће пажњу са битних детаља. Управо због свих тих елемената општег утиска о особи са којом се комуницира, много је мање учешће говора односно речи. Приликом директног сусрета, особа описује себе и другим средствима која нису вербална. Тако можемо да посумњамо у искреност представљања ако нам се учини да се никако не слаже оно што видимо са оним што чујемо. Постоји увек и мера, граница до које ће неко говорити о себи, или уопште говорити, а то зависи од много фактора као што су стидљивост, обичаји, околности, навике а увек су важне и реакције на лицу саговорника. У виртуелном свету, падају многе границе и мере јер је довољан мали подстицај да човек проговори о себи, нарочито ако нема много прилике да то чини у реалном окружењу, било због неразумевања ближњих, усамљености или других разлога. С друге стране, комуникација на мрежама је претежно вербална. Слике, клипови и остало што се прилаже као брош уз сопствено виртуелно име, може бити вештачки компоновано. Стога се прате речи, вербални описи стања. То је можда основна разлика сусрета на мрежи и сусрета у стварности. На мрежи царују речи а у директном сусрету многи детаљи који не измичу оку и интуицији. Стога је реално претпоставити да је губитак критичке дистанце, у односу на стварност и меру, веома могућ у виртуелном свету.

Много тога потиче из потребе за експанзијом или ширењем идентитета. 
Виртуелне технологије омогућавају остварење сна карактеристичног за западна друштва а то је сан у којем се повезују жеља за личном експанзијом изнад и изван граница тела са фантазијом савршене мере психичког благостања. Ова фантазија као манифестација личне унутрашње истине постаје морално допустљива у виртуелном свету (Hillis 204).

\section{Поцепана стварност}

Изразита посвећеност виртуелном или објективном свету комуникација је чешћа код млађих корисника. Старији корисници су ставили та два света један крај другог, мешају их по потреби у обе врсте комуникације и сматрају престижним питање активног учешће у оба света као и лако сналажење у раскораку онога што говоре на мрежи или у животу. Ово је слично начину на који јавне личности покушавају да помире приватну слику о себи са оном јавном коју су пласирали сами или уз помоћ медија. Од лоших последица је лакше дистанцирати се ако се једном ногом стоји у суровој стварности а другом у виртуелном свету. Сваки од светова може бити добар изговор за одрицање од неког свог дела, речи или створеног утиска у оном другом свету. Ову врсту изговора могу користити претежно старији, искуснијии мудрији учесници комуникација на паралелном колосеку.

Постоји и додатни проблем херметичног језика из виртуелног света који у објективној стварности користе они који су активни на мрежама. Они помињу детаље другима непознате или користе фразе које звуче као непознат страни језик. Ово настаје из жеље да се уклопе у модерне трендове али и да се уздигну изнад оних који још нису крочили свим срцем или у довољној мери, у виртуелни свет комуникација. Појавила се, значи, нова форма и разлог социјалног одбацивања оних који нису на мрежи и аутоматски се по нечем суштинском разликују од оних који јесу виртуелно активни. Људи теже да буду дефинисани, да се могу описати и да бар у некој мери личе на оне чији део друштва желе да буду. Навика да се буде негде или ради нешто налик другима није исто што и суштинско угледање на 
позитивне моделе из објективне околине и њихове личне карактеристике, било да су исказане у објективном, виртуелном или новом трећем свету у којем се срећу прва два.

\section{Закључак}

Процес културне размене на новим медијским платформама спушта се до нивоа сваког појединог корисника док ми и не примећујемо убрзавање процеса рађања једног новог глобалног културног ентитета. Већ сада тај глобални медијски систем може представљати и одраз културног империјализма. Извоз медијских садржаја путем нових компјутерских технологија обезбеђује доминацију и превласт медијских садржаја из само једне или тек неколико земаља, и то путем индустрије маркетинга и забаве или просто извоз неке локалне поп културе која потом представља удар на културне особености осталих људи и земаља. Припадници антиглобалистичког покрета наглашавају ову опасност од неповратног нестајања културних различитости. На другој страни су глобалисти који наглашавају значај окупљања различитих учесника комуникације на једном месту као и развоја толеранције за све врсте међусобних разлика. Колико јуче је било скоро сасвим немогуће окупити толико људи на једном месту док је сада ту овај нови облик реалности, назване виртуелном, која има огроман утицај у овом месту које још увек сматрамо јединим истинским реалним простором.

Три најважнија процеса започета развојем технологије и успостављањем квалитативно унапређених, нових комуникација су:

1. к о м п р е и ј а или сажимање времена и простора,

2. си н те з а културних особености и

3. пр екл а п а њ е два основна нивоа реалности, физичке и виртуелне у једну нову, свеобухватну али за сада још увек поцепану стварност.

За крај се чини прикладном парафраза Ничеове дефиниције филозофије, науке коју он сматра и назива носталгијом, јер ми данас скоро на исти начин можемо дефинисати виртуелни свет :

- Виртуелни свет је права носталгија: то је жеља да се буде свугде али код куће!- 


\section{Литература}

Dodge, Martin and Kitckin, Rob. Mapping Syberspace. NY, US: Routledge, 2003. Hillis, Ken. Digital Sensation. Min., US: University of Minnesota Press, 1999. Holmes, David. Virtual Globalization. NY, US: Routledge, 2002.

Jaeger, Paul T., Burnett, Gary. Social context, Technology and Information, Behavior in the age of the Internet. NY, US: Routledge, 2010.

Jones, Steven G. Virtual Culture:Identity and Communication in Cyber society. London, UK: Sage Pbl. Ltd., 2002.

Martinsen, Oyvind L. "The Creative Personality: A Synthesis and Development of the Creative Person Profile". Creativity Research Journal, 23 (3) (2011): 185-202.

Sorrells, Kathryn. Intercultural Communication - Globalization and Social Justice. California, US: Sage Publ. Inc, 2016.

Jelena Radović Jovanović

\section{VIRTUAL REALITY: THE FADING BORDERS OF CLASSICAL REALITY CONCEPT AND INDIVIDUAL DIFFERENCES}

\section{Summary}

Global postmodern reality illusion emphasizes all the beaty of cultural differences but it also presents the threat of making them more similar or even fading them all out. New media platforms are constantly providing the process of globalization with all the necessary elements.

Globalization is an extensive, interactive and live communication model and the major part of it takes place in virtual spaces of new media platforms. In the very heart of this communication globe are multiple connections getting stronger every day. This ball is getting bigger and bigger so that any kind of borders or measures are no longer applicable variables when we talk about this dynamic concept. This is a place of a real inspiration for making first steps towards new creation which rejects passivity and engages one concious and critical approach.

Important parts of this virtual puzzle are personal sites and, right after them, numerous commercial sites in search for future clients or consumers. Virtual social networks have become almost real places where one can get support, social acceptance and approval. 
Cultural exchange on new media platforms has a capacity of reaching every single individual user. Still, we miss to notice the speeding process of a new global cultural entity. This global media system may have allready become the reflection of acultural imperialism. The export of media contents throgh new computer technologies guarantees the domination of one or just a few countries through their marketing or entertainment industries or just local pop culture that strikes cultural distinctiveness of other people and countries. While anti-globalists emphasize this as a danger, on the other side are globalist greeting the gathering of all kind of differences on one place and rising the spirit of tolerance. Today we have this new type of reality, called virtual, with an enormous influence on the place which we still consider to be the only true real space.

Key words: Reality illusion, cultural differences, cultural globalization, real and virtual space, communication globe, dynamic concept, personal and commercial sites, global cultural entity, cultural imperialism, cultural distinctiveness 